\title{
Plato's queer time: dialogic moments in the life and death of Socrates
}

The contemporary concept of 'queer time' can be used to provide new answers to problems of temporality and anachronism in Plato's Socratic dialogues, problems that have concerned scholars since antiquity. Critics, from Athenaeus in the second century CE and Eduard Zeller in the nineteenth, to the present day, have been concerned with problems of authenticity and the dating of Plato's work, including the inconsistent internal dramatic dates of the dialogues. ${ }^{1}$ However, the way in which Plato uses the temporal setting of dialogues to underscore themes of their arguments can be read as an artefact of Plato's own reception of Socrates' life and death, and its context in the turmoil of the Peloponnesian War and the loss and restoration of democracy.

This paper examines the relationship between the imaginary time of the dialogues and Plato's own context, between the blurring of time and temporal relationships in the dialogues and the arguments that they contain, the construction of anachronistic communities and genealogies within them, through which Plato negotiates his own relationship with Socrates, and the deconstruction and re-negotiation of familial relationships, particularly those between fathers and sons. It uses insights from recent explorations of temporality in queer theory to generate a historicist reading that emphasises the affective role of time within Plato's writing. ${ }^{2}$ Reading the dialogues anachronistically, as if they were a work of creative nonfiction, akin to Robert Graves' wartime poetry and memoirs, Eve Kosofsky Sedgwick's

${ }^{1}$ Zeller 1873, Athenaeus Deipnosophistae 5.218bc, 11.505f-506a. Nails 2002: 308-30 catalogues possible dramatic dates for the dialogues. See also Graham 2007.

${ }^{2}$ Winnubst 2010 and Freeman 2007 offer introductory surveys of the relationship between queer theory (on which see Jagose 1996 and Turner 2000) and temporality. 
combination of academic and personal writing, such as her essay 'Queer and Now', or Maggie Nelson's account of her intellectual and personal relationships in The Argonauts, reveals both a constructed timelessness and an affective model of time that exemplify 'queer time' ${ }^{3}$

Plato himself, in his later dialogues, points to a philosophy of history and periodisation, but his own non-linear construction of Socrates' biography in his earlier dialogues demonstrates a distinctive use of time and temporality. ${ }^{4}$ Socrates and other characters are manipulated in time and space to move them together so that they can converse face-to-face. Philosophies and pedagogies are identified by their attitudes to time; their reliance on the authority of the past, their use of past people and events as the basis of exemplarity, their access to the metaphysical and epistemological states of being and becoming. These identifications in turn interact with the argumentative content of the dialogue, conditioning our reading. Socrates himself, like the mediaeval mystic Margery Kempe in Carolyn Dinshaw's account, appears on occasion to exist asynchronously, separately from the time experienced by those around him, perhaps facilitated by the presence of his daimonion with its messages from the divine world, and suggesting that Plato positions him more closely to the eternal. ${ }^{5}$ In one discussion of the mystic experience, Dinshaw notes that for Margery Kempe: ${ }^{6}$

${ }^{3}$ Graves 1916, 1960, Nelson 2015, Sedgwick 1994: 1-20.

${ }^{4}$ On the later dialogues see Broadie 2012, Gill 1977.

${ }^{5}$ Dinshaw 2007, 2012.

${ }^{6}$ Tim Rood observes that in her revised version, Dinshaw notes that the priest regards Kempe as 'a pathetic anachronism' but that Kempe herself feels 'asynchronous' (Dinshaw 2012: 106-07). 
the point is immediate access to Christ now...Her time, her present, her now, is defined by its being invaded or infused by the other: the pietà out there becomes the pity in her. That's what it feels like to be an anachronism; she is a creature in another time altogether — with another time in her, as it were. (Dinshaw 2007: 108)

Like Dinshaw’s Kempe, Plato's Socrates is differentiated from those around him by his individual temporality. Even while living and dying he emanates the changeless time of being, not that of changeable becoming, showing his familiarity with the timeless underworld, a connection further emphasised by Plato's frequent use of the katabasis as theme and structure for his dialogues. ${ }^{7}$ His dramatised life reflects the deeper Platonic concern for being over becoming, for the intellectual and eternal world of the Forms rather than the physical and mortal world of becoming and bodies.

\section{Queer times ancient and modern}

Queer theory offers a fruitful approach to understanding the temporal structures of Platonic dialogue and its representation of a non-normative life. Theories of queer temporality emerged from various perspectives, but share interesting consequences for the study of anachronism, in part because of their heritage from Foucault's exploration of intellectual history (Foucault 1977, 1976). Valerie Traub has suggested that analogical reasoning is 'especially suited to queer analysis', and this paper points to analogies between Plato's response to societal and individual crises and to those described by more recent writers (Traub 2013: 30)

${ }^{7}$ Burnyeat 1998: 5-8; on Plato's distinction between the states of being and becoming, see Frede 1988. 
Firstly, there is the sense of political and social crisis generating a distinctive experience of temporality, the recognition of a foreshortened future, seen in responses to two events which brought suffering and early death to many, World War I and the flu pandemic early in the twentieth century, and the AIDS crisis at its end. This can be seen in Eve Kosofsky Sedgwick's Tendencies, which provides a framework for her theoretical thinking, more clearly expressed in her Epistemology of the Closet, through the memorialisation of friends and their loss, and reflections on her own illness, and in her identification of a cultural crisis for modernity in the response to homosexuality. ${ }^{8}$ Tim Dean (2011) makes explicit the problematic relation with time realised in the foreshortened future of those affected by the AIDS crisis, especially before the development of effective treatments for the condition.

For Plato, as for Sedgwick and Nelson, philosophy is framed through personal experience; although Plato is almost entirely absent from his texts, and makes few explicit authorial observations, his choice of material and particularly the way in which he depicts philosophical argument in the conversational encounters of Socrates show the impact of traumatic historical events on his life. Sara Monoson has shown that one way in which Plato differentiates Socrates from other Athenians is to show his resilience to trauma as a combat soldier, within a society where war is a universal experience (Monoson 2014: 135-39). The conviction and death of Socrates in 399 BCE and the turmoil of the collapse and reconstruction of Athenian democracy a few years previously provide a similar moment of crisis that becomes the focus of his reshaped past. ${ }^{9}$ This crisis looms over dialogues even

\footnotetext{
${ }^{8}$ Sedgwick 1994, cf. Sedgwick 1990: 52. See also Barber and Clark 2002, Gallop 2011. ${ }^{9}$ The Seventh Letter (324b8-326b4) extrapolates Plato's response to Socrates' death from authentic Platonic texts. See Schofield 2000, Burnyeat and Frede 2015. Francis Dunn argues that the late fifth-century was a period of 'cultural shock' in Athens (Dunn 2007).
} 
when it is in their dramatic future, through frequent proleptic references to Socrates' trial itself and to the risk to philosophers of speaking in the city. His accusers intrude into the text, as with the antagonistic presence of Anytus, who brought the impiety charges against him, towards the end of the Meno. ${ }^{10}$

Secondly, queer theory identifies a problematic orientation towards time, affecting attitude to both past and future. Lee Edelman's No Future critiques use of the heteronormative ideals of reproduction as an analogy. ${ }^{11}$ Edelman problematizes the figure of the 'child' as the emblem of social continuity, and the 'reproductive futurism' this implies, the heteronormative assumptions of investment in the future through sexual reproduction:

Indeed, at the heart of my polemical engagement with the cultural text of politics and the politics of cultural texts lies a simple provocation: that queerness names the side of those not 'fighting for the children', the side outside the consensus by which all politics confirms the absolute value of reproductive futurism... (Edelman 2004: 3)

The past too evokes complex emotions. A longing for a time when the life one wanted to lead was difficult and subcultural informs Jack Halberstam's nostalgia for dyke subcultures in The Queer Art of Failure. ${ }^{12}$ One might see an analogy between nostalgia for a sub-

${ }^{10}$ P1. Meno 89e-95a; Scott 2006: 162-73.

${ }^{11}$ Edelman 2004, cf. Dean 2011.

${ }^{12}$ Halberstam 2011. Previously, Halberstam wrote of the 'anachronism' of the 'inversion' model of gay and transgender identities (Halberstam 2005: 34-35). 
cultural life lived in difficult circumstances and Plato's depiction of the struggles of philosophers and their rivals in democratic Athens. ${ }^{13}$

However, this is a much-contested area in queer theory and perhaps the hardest to apply to Plato's thought; relation to past, present and future is thought to differ in ancient thought and modern, and an ancient assessment or rejection of the potential futurity of a life might differ from a modern one. ${ }^{14}$ But considering how ethical choices are made from the standpoint of foreshortened lives lived in times of social and political crisis may help us to read Platonic ethics generated in a time of crisis. Such a reading enables us to recalculate the hedonistic calculus for ancient lives in a context where the most likely future for a life is brief and uncertain, as it is for many of Plato's characters.

Thirdly, this concern extends into a critique of heteronormative analogies in the structuring of accounts of the past, such as that inherent in Foucault's model of genealogy. ${ }^{15}$ Plato constructs new genealogies and connections for Socrates, participating in if not inaugurating a tradition of anachronistic intellectual history, in which plausible chronology is subservient to the construction of accounts of intellectual inheritance. Valerie Rohy's claim is that queerness (in parallel with race, in the context of the USA) disrupts the 'fantasy' and 'linear temporality' of straight time, the 'normative temporality'. ${ }^{16}$ She echoes Edelman's model, seeing gay lives as failing to complete the passage through the life-stages valued in a

${ }^{13}$ The Straussian emphasis on the danger inherent in choosing the philosophical life might be seen as a portrayal of philosophy as a counter-culture or sub-culture (Strauss 1941).

${ }^{14}$ On ideas of futurity in antiquity, and shifting valuation of past, present and future in historiography, see Greenwood 2016 and Lianeri 2016.

${ }^{15}$ Edelman 2004, Freeman 2010.

${ }^{16}$ Rohy 2009: xv; see also Rohy 2011, 2015. 
heteronormative framework, as does Halberstam (Halberstam 2005). Labelling Plato's time as queer might itself be anachronistic, given Foucauldian restrictions on the retrojection of modern conceptualisation of sexuality and sexual identity into the classical world, but the range of atopic and non-normative behaviour exhibited by Socrates seems analogous to a broad sense of 'queer' as well as to the temporally disruptive 'queer' developed by Edelman and Halberstam. ${ }^{17}$ Plato authorises this reading by introducing Socrates as a character whose inexplicable behaviour transgresses a series of social norms, often related to time and temporality.

Plato extensively signals the non-normativity of Socrates' behaviour, with characters describing him as atopos, out of place or in the wrong place, and exhibiting atopia. Atopia is a condition applicable to features of unusual events, as Thucydides notes in describing the transmission of stasis from Corcyra to other cities, and the escalating 'strangeness ( $\dot{\alpha} \tau$ o $\pi_{i} \alpha$ ) of ... reprisals' (Thuc. 3.82.3). ${ }^{18}$ Plato's characters acknowledge this in their attempts to describe Socrates' multi-faceted strangeness and that of his ideas, as the anonymous observer

${ }^{17}$ Foucault 1978; Rohy 2009: 126-30. Foucault's warnings on the anachronism of retrojecting modern sexual and gender identities into the classical past have framed much discussion of ancient sexuality: see Halperin 1990, Halperin in Blondell and Ormand 2015, as well as contributing significantly to discussions of queer temporality (Winnubst 2010). On queerness, see Dinshaw 2012: 31-35, Nelson 2015: 28-30; Nelson considers the factors that enabled Sedgwick, a figure to whom she feels a complex sense of filiation $(30,105)$, to connect herself with the queer experience.

${ }^{18}$ Thucydides also suggests that atopia makes it difficult to generalise from experience, as in accounts of the plague at Athens (2.51.1). 
often identified with Isocrates does in the Euthydemus (305a3-4). In the Phaedo, Socrates reinforces his strangeness and outsider status in his opening observation:

'What a strange thing ( $\dot{\varsigma} \varsigma$ ö $\tau o \pi \circ v)$ it seems to be, friends, this thing which people call pleasant.' (Phd. 60b3-4)

Alcibiades, in his disruptive and drunken entrance in the Symposium, finds Socrates' strangeness difficult to describe, as he attempts to narrate and classify the age-reversed (and in a sense queered) pederastic relationship he has sought with him:

If however, in recalling events, I tell them out of order ( $\left.\alpha^{\prime} \lambda \lambda o \alpha^{\prime} \lambda \lambda \circ \theta \varepsilon v\right)$, don't be

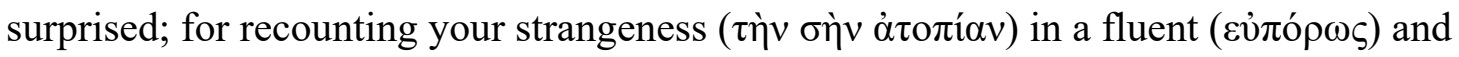
orderly manner is not an easy thing for someone in my state. (Smp. 215a1-3)

Although atopia implies a spatial concept, in Socrates it takes a temporal form. Earlier in the dialogue Socrates' strangeness has manifested itself as a refusal to operate at the same speed as others, standing still rather than completing his journey, and failing to arrive at the party to which he'd been invited. Aristodemus, tagging along uninvited with Socrates but arriving before he does, responds to Agathon's query:

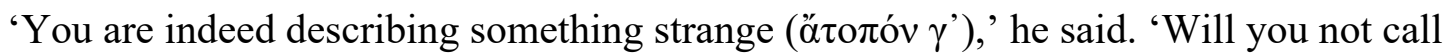
him and not let him go?'

And he said that he said: 'Absolutely not. Let him be. For this is his habit ("'0os). Sometimes he stops and stands wherever he happens to be. But he will come right away, in my opinion. So don’t disturb him, but let him be.' (Smp. 175a10-b3)

Socrates' atopia has disrupted the proper order of events, in which he should have arrived first and introduced Aristodemus as his guest, but the younger acolyte arriving first has to introduce himself and explain what is happening. Socrates' atopia here takes the form 
of resisting movement and the progression of time, connecting himself to the static state of being, related to the Forms, rather than the moving state of becoming.

Plato elsewhere identifies a specific kind of atopos time. Part way through the second part of the Parmenides, in which the eponymous philosopher demonstrates to the listening Socrates that there are errors in his developing theory of Forms, Parmenides considers the problem of the temporality of the One. He asks whether there is a moment in which the One passes between states (or from process to state), such as from motion to rest:

So what is the strange (ö $\tau$ o $\pi$ ov) thing, in which it is at the time when it changes? (Prm. $156 \mathrm{~d} 1-2)$

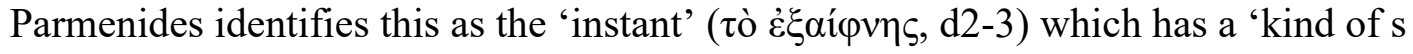

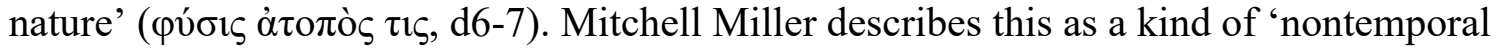
being' (Miller 1986: 112-13). ${ }^{19}$ The Instant's queerness places it outside time (156e1), but Plato also uses the word to articulate transitions such as epiphanic encounters with knowledge, as with Diotima's description of the recognition of Beauty (Smp. 210e4). As an adverb the word also describes Alcibiades' noisy arrival soon afterwards (Smp. 212c5), in which, as we saw, he will describe Socrates' atopia. Socrates' queerness, it seems, has a temporal dimension.

\section{Temporal fluidity}

Plato uses the reversals of Athenian politics at the end of the Peloponnesian War and the trial and execution of Socrates to generate an unreal kind of time for his dialogues, subject to

${ }^{19}$ Rangos 2014 explores the 'nature of the sudden moment' in these dialogues, and the extensive scholarship on its role in the Parmenides exercises, but does not link them explicitly with atopia. 
acceleration and deceleration, temporal collapses and incursions, and, with its moments of stillness, resistant to linear narrativisation. This unreal time echoes the queerness identified by Elizabeth Freeman in her reading of Robert Graves' poem 'Queer Time', in which the separate times subject to collapse are expressed in terms of sexual experience and identity (Freeman 2010: ix-xii). ${ }^{20}$

Graves depicts the experience of a soldier facing death in the trenches as one of temporal and spatial collapse, in which he re-experiences past encounters and people as he comes under fire. The first two (of five) stanzas read:

It's hard to know if you're alive or dead

When steel and fire go roaring through your head.

One moment you'll be crouching at your gun

Traversing, mowing heaps down half in fun:

The next, you choke and clutch at your right breast -

No time to think - leave all - and off you go ...

To Treasure Island where the Spice winds blow,

To lovely groves of mango, quince and lime -

Breathe no good-bye, but ho, for the Red West!

It's a queer time.

You're charging madly at them yelling 'Fag!'

When somehow something gives and your feet drag.

You fall and strike your head; yet feel no pain

${ }^{20}$ While Graves' 'queer' is atopos rather than sexually explicit, other readers of Graves' early poetry have detected a queer concern with gender in poems such as 'A Renascence' (Drake 1970: 26-27, Brearton 2009, cf. Xenophon's description of Persian captives at Hell. 4.3.19). 
And find ... you're digging tunnels through the hay

In the Big Barn, 'cause it's a rainy day.

Oh, springy hay, and lovely beams to climb!

You're back in the old sailor suit again.

It's a queer time.

Graves' character experiences the bravado of war, and confused temporal experience as the character relives past experiences in the moment of death, from the pleasurable sensual experiences of childhood play and its imaginary worlds to more adult pleasures, with a heightened sense of physical intimacy. ${ }^{21}$ Graves wrote further on his experiences of the First World War and the 1918 flu pandemic in his autobiographical Goodbye to All That (Graves 1960, originally published 1929). In that work, and others of the immediate post-war era, the advent of modernity itself is a form of queer time; at the other end of the twentieth century, the AIDS crisis generated a further sense of temporal foreshortening, documented by Sedgwick in framing her theoretical project:

It was a queer time...

In the short-shelf-life American marketplace of images, maybe the queer moment, if it's here today, will for that very reason be gone tomorrow. (Sedgwick 1994: xi-xii ) ${ }^{22}$

${ }^{21}$ Although the most eroticised images of combat in Greek art are those featuring the hero Achilles and the Amazon queen Penthesilea, depicted by Exekias on a black-figure amphora (British Museum 1836.2-24.127).

22 In 'Queer and Now' (Sedgwick 1994: 1-20), Kosofsky Sedgwick also notes the high incidence of suicide among young LGBT people in a closeted culture, and how 'queer survival' impacts others: she describes 'the omnipresence of somatic fear and wrenching 
Plato too hints at a crisis by marking his absence through illness from Socrates' deathbed: 'But Plato I think was ill' (Phd. 59b10).

Plato manifests the non-normativity of Socrates by depicting challenges to normative masculine behaviour through the manipulative performance of homosocial practices such as pederasty. ${ }^{23}$ This is inevitably linked to temporality given the centrality of age and physical maturation in the identification of the idealised eromenos. The Protagoras uses this temporal concern to frame a dialogue which evaluates intellectual activity on the basis of temporal positioning and attitudes to the past. Its opening scene emphasises the analogy between pederasty and philosophy, between the attractions of Alcibiades' maturing body ('just the beginnings of a little beard') and Protagoras' thinking (Prt. 309a1-b2). Protagoras' ideas, which Socrates claims are more beautiful to him than Alcibiades' body is, may also, by analogy with the body, be prone to change and to decay; there is a subtle allusion to the historical Protagoras' interest in temporality. ${ }^{24}$ Variation in the speed of speech and argument is also strongly marked in this dialogue, as an analogy between length of speeches and longand short-distance running suggests (Prt. 335d6-336a5).

The unstable tempo of narration occurs throughout the dialogues. Like the subject of Graves' poem, Socrates is depicted in time that both speeds up and slows down as he

loss' (p. 3), the importance of affirming queer perspectives, and invokes Plato as the starting point for a project on queer performativity to deliver that goal (p. 11).

${ }^{23}$ On Socrates and Alcibiades, see Wohl 2002: 158-70; Halperin 1986 and Gordon 2012 offer a broader investigation of Socratic erotics.

${ }^{24}$ See Dunn 2001, with Dunn 2007: 44-57 on the broader context of sophistic thought on time. 
approaches his trial and death. The norms of narrative time are dissolved through Socrates' atopia .

\section{Intimations of immortality}

One temporal differentiation is that between the time of the living and the time of the dead, of continuing steady-state of eternity versus the growth and decay of the mortal life. Plato problematises the question of whether Socrates, with his connection to the eternal and the divine, is alive or dead; the living character of the dialogues versus the man executed in 399 BCE. In the Apology Socrates pictures himself continuing his philosophical practice as part of an anachronistic community in the underworld (Apol. 40c-41c), and descriptions of experiences there recur in the Gorgias and the Republic, with its recurrent katabasis motif.

The brief period prior to Socrates' trial and death provides the setting for many important dialogues. The pace of philosophical action involved in this cluster results in a form of temporal compression hinting at authorial anxiety and loss of control. Equally, this critical moment diminishes the division between the historical Socrates' thought and Plato's attributed ideas. ${ }^{25}$ The Phaedo explores the space between death and life in its argument and in its narrative, ending with Socrates' death after he has given a powerful and vivid account of the progress of souls through the underworld. Plato uses the dialogue's temporal proximity to Socrates' death to emphasise this discussion of the immortality of the soul.

But even in this dialogue, Socrates' life is prolonged through the agency of Apollo or chance disrupting the usual chronology of judicial process. Socrates' execution, expected to be imminent, is delayed, extending his life so that he is able to sing his swansong to the god (84e-85b), and to report on the underworld (112e-114c), before finally drinking the hemlock.

${ }^{25}$ See Vlastos 1991: 45-80 on Plato's use of Socrates as a character. 
The Athenians send a ship to Delos on a sacred mission 'every year from that time in the

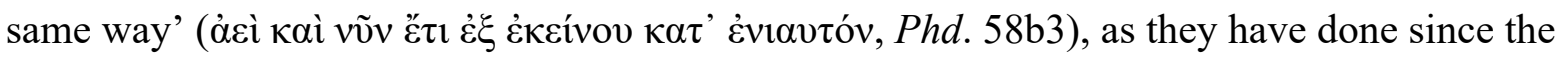
return of Theseus from Crete, but in some years the city marks a longer period of purity because of the mission takes longer than usual. This time, unfavourable winds have delayed the mission's return, so the execution is delayed while the city's religious purity is maintained (Phd. 58bc).

Plato exploits this opportunity, which makes narrative time flexible and permits this lengthy discussion, itself concerned with eternity rather than the linear time of human life. But the Phaedo's structure does not disconnect Socrates entirely from the world of the living. Unusually, Plato makes the frame dialogue break into the narrated section at two points. ${ }^{26}$ The first interruption occurs after Cebes' analysis of the 'attunement' argument for the immortality of the soul (88c-89a), just before Socrates' famous strictures against misology. The second, briefer interruption follows a dense section of argument on method (102a). Simmias and Cebes, Socrates' interlocutors, agree, and Echecrates, listening to Phaedo's narration, bursts in to agree with them, encouraging the reader to do the same. Socrates and his interlocutors debate one kind of immortality, the continuing community of readers are linked into the discussion to provide another.

As Socrates reviews arguments for immortality, then describes a journey through the underworld, we see him positioned at a critical point in a cycle of life, at the timeless instant of the state change between living and dying. Plato's work draws on mystery and Pythagorean traditions concerned with experience in the afterlife. In the context of

${ }^{26}$ The Euthydemus uses the same structural device, but with Socrates as a speaker in both frame and dialogue. 
reincarnation, recollection and metempsychosis, the experience of lived time is challenged. ${ }^{27}$ Just like Dinshaw's Margery Kempe, Socrates' visions challenge lived human time by suggesting a life lived in multiple temporalities that have been collapsed into contemporaneity. Dinshaw's observation that Kempe was aware that her 'intense corporeal performance' of this experience was annoying to others echoes Socrates' self-description as a gad-fly for the Athenians. ${ }^{28}$

The awareness of imminent death and a restricted future Tim Dean's exploration of the temporal experience of mortality experienced in response to the advent, first of AIDS as a fatal disease, and then of treatments that replaced the certainty of the disease's progression with an 'altered tempo' of 'new anxieties' in which patients enter the 'double temporality' of the 'suspended death sentence': We are inhabited by asynchronous temporalities whose disjunctive syncopation exerts a constant pressure on our lives. Like ghosts, what inhabits us is neither unequivocally dead or alive. (Dean 2011: 92)

Dean suggests that, for some, this anxiety can only be resolved through the acquisition of HIV-positive status, rendering the activities of 'barebackers' a rational choice. ${ }^{29}$ Socrates' death sentence clarifies the remaining extent of his life, and induces a similar calm into his exploration of immortality in the Apology and the Phaedo. This supports his principled refusal to escape from Athens and his punishment, the subject of the Crito; flight would return him to the uncertain temporal status of other humans.

${ }^{27}$ Such as mystery texts like the Derveni papyrus (Betegh 2004).

${ }^{28}$ Dinshaw 2012: 113-14; Pl. Apol. 30a.

${ }^{29}$ Dean 2011: 76-77. Dean's argument is that 'barebackers', men engaging in unprotected sex that risks HIV transmission, are 'experimenting... with what it might mean to selfconsciously expose oneself to temporal contingency and to finitude'. 


\section{Biographical compression}

While Plato's Phaedo depicts a delay and moment of calm, other dialogues whose dramatic setting is within Socrates' final weeks weave into each other in the run-up to his trial and execution, marking their seriousness as his swan song (Phd.85a9-b7) through their proximity to his death. By inserting the final dialogues in which Socrates appears into a position very late in his life, Plato imbues them with authority.

The Theaetetus, perhaps the most complete exploration of epistemology in Plato's work, inserts itself into a biographical timeline but also disrupts it; at the end of the dialogue, Socrates leaves the discussion with Theaetetus to visit the office of the basileus archon:

And now ( $(\tilde{v} v \mu \varepsilon \dot{v})$ I must go to the king archon's office to meet the indictment which Meletus has brought against me; but in the morning ( $\check{\varepsilon} \omega \theta \varepsilon v \delta \varepsilon$ ) let us meet here again

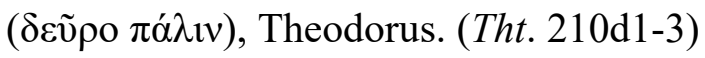

As readers of the corpus we know that this will be the occasion of the Euthyphro, which takes place outside that office, an unusual place for Socrates to be given its association with the administration of Athenian politics and law, as Euthyphro's opening question suggests (Euth. 2a1-3). This dialogue, thought to be an earlier composition, gives no hint that Socrates has passed the day exploring epistemology; it invokes the same temporal setting for affective reasons, rather than to mark an absolute chronology.

The Theaetetus is the first in a sequence of dialogues said to take part on consecutive days, followed by the Sophist and the Statesman (Soph. 216a1-4, Plt. 258a2-6). The opening of the Sophist introduces a new character, the Eleatic Stranger, and links these dialogues to Plato's Parmenides by invoking his intellectual genealogy as an alternative to his familial one: 
Theodorus: In line with yesterday's agreement, Socrates, we've come here ourselves in an orderly fashion and brought this visitor here. His family is from Elea, but he's a friend of Parmenides' and Zeno's followers, and above all he's a man who loves wisdom. (Soph. 216a1-4)

Plato thus links the Sophist to the Parmenides, in which Zeno and Parmenides themselves challenge the ideas of a youthful Socrates, a dramatic setting that is itself chronologically improbable. The Eleatic Stranger's links to them emphasise the dialogue's philosophical continuity with the Theaetetus.

The frame dialogue of the Theaetetus emphasises its temporal problems. The conversation is explicitly described as having been preserved in written form:

Terpsion: But what was this discussion? Could you tell it to me?

Euclides: Good lord, no. Not from memory ( $\alpha$ ì $\sigma \tau o ́ \mu \alpha \tau o \varsigma)$, anyway. But I made some notes (i $\pi \circ \mu v \eta \dot{\mu} \mu \tau \alpha)$ of it at the time, as soon as I got home; then afterwards I recalled it

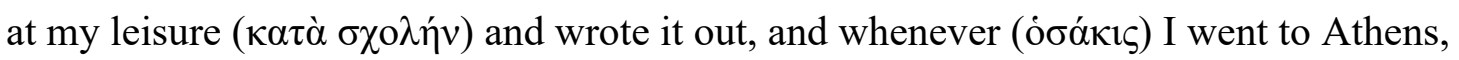
I kept on asking ( $\dot{\pi} \pi \alpha v \eta \rho \omega ́ \tau \omega v)$ Socrates about the points I couldn’t remember, and correcting my version when I got home. The result is that I have got pretty well the whole discussion in writing ( $\gamma \varepsilon \dot{\gamma} \gamma \rho \alpha \tau \alpha \imath)$. (142e6-143a5, translation Levett/Burnyeat)

This frame itself introduces some temporal perplexities. If its writer Eucleides was able to write it down, then read it to Socrates for corrections on repeated occasions (as the imperfect verb with its double prefix suggests), this must have happened over a compressed period, the short remaining time of Socrates' life from his accusation to execution. On a linear reading of Platonic temporality much of this time is taken up with other philosophical conversations. The project seems impossible in linear time, if repeated journeys from Megara were needed, and Eucleides recalled and wrote 'at leisure'. Although both the Theaetetus 
discussion's nominal writer Eucleides and his listener Terpsion are present at Socrates' death bed, unlike Plato (Phd. 59c2), even the extended period of Socrates' imprisonment makes this leisurely process hard to fit into a linear chronology. The difficulties of the temporal framework mark the fictive construction of the dialogues.

Just as the conversation with Euthyphro is not linked to the dialogues entangled with it, the Eleatic Stranger has apparently disappeared from Socrates' presence by the time that the Phaedo's main conversation takes place, at the end of his elongated imprisonment, despite the presence of many visiting thinkers at Socrates' deathbed. Plato turns to this period in Socrates' life not to document actual conversations in chronological order but to assert the importance of the arguments presented in each dialogue. This clustering of dramatic dates for texts written at different points in Plato's writing career suggests a febrile atmosphere and an acceleration towards disaster. Various clues and connections between the dialogues create an impression of crisis that is in tension with the philosophical content of the dialogues while it simultaneously asserts its importance.

Plato's crowding of dialogues in the last weeks of Socrates' life is a qualitative rather than a chronological choice. It generates an affective time rather than a historical chronology, in which the importance of discussions and their seriousness is marked by their position relative to Socrates' trial and execution.

\section{Fathers and sons}

Socrates' pedagogic efforts also challenge filiation, a process that is important in many dialogues, as the inability of fathers to pass on their virtues to their sons is paralleled by the creation of non-familial genealogies. As Barry Strauss noted, 'For Athenians the father-son relationship served as a powerful, multivalent symbol of authority' (Strauss 1993: 21). The problematics of such relationships, and their potential as analogies for changing ideas and 
social practices, was a stock element of Aristophanic comedy, displayed for example in the Clouds and the Wasps (Strauss 1993: 157-62). When Socrates intervenes between fathers and sons, as the ancient charges against him of 'corrupting the young' suggest (Apol. 24b8-9), he disrupts a relationship freighted with social, economic and political significance. ${ }^{30}$ This applies as much to his appearance in Aristophanes' Clouds (among the 'first accusers', Apol. 18a9) as to Plato's later depiction of him. Plato shows Socrates outlining alternative modes of social reproduction, that eliminate the role of women and assert a model of male intellectual reproduction, in his Symposium and Theaetetus. ${ }^{31}$ He corrupts the order of a city whose citizen body is legitimated through its inheritance from both parents. ${ }^{32}$

By removing youths from their familial tree into orders of philosophical succession, Plato recreates and parodies the temporality of succession, as later receptions acknowledge. In his Envois, Jacques Derrida takes up the depiction of Socrates and Plato by Matthew Paris in a thirteenth-century CE manuscript, a depiction that, as Ika Willis notes, engages tropes of queer culture that play with and parody father-son relationships. ${ }^{33}$ Derrida here notes the importance of Plato's father-son imagery, picking up on his earlier exploration of this theme

${ }^{30}$ Strauss 1993: 199-209 reads Plato's Apology as a representation of the opposition between Socrates and 'the Athenian father'.

${ }^{31}$ On the deeply vexed question of Plato's attitude to women and sexual reproduction, see Annas 1976, Irigaray 1985, and Nicole Loraux on related Athenian ideological myth (Loraux 1993: 45-71).

${ }^{32}$ In force while the historical Socrates was active in the city; see Arist. [Ath. Pol.] 26.4.

${ }^{33}$ Bodleian Library, MS. Ashmole 304, fols. 31v-32r; Derrida 1987, Willis 2010. See also Wohl 1998 on filiation as a theme of the Platonic Epistles, and Derrida 1981: 71-86 on Plato's connection between writing and filiation in the Phaedrus. 
in the Phaedrus, and suggesting that Plato generates a father-son relationship between himself and Socrates. But in the dialogues themselves, Socrates' disruptive incursions into father-son relationships problematise filiation; he falls between the two generations, as in the Protagoras and the Laches.

Plato uses genealogy extensively as an analogy to account for the transmission of Socratic dialogues, the connections between different generations, and it is a form of accounting for the past that is particularly important in ancient intellectual history, as well as one that is notoriously resistant to precise chronology as the creation of links between founders and successors overrides any concern about historicity. The transmission of the Symposium is expressed in an oral genealogy that resembles the stemma of later manuscript transmission (Smp. 172b9-173b8) and suggests an attempt to present it as documentary evidence. Plato notes the analogy between textual transmission and genealogy explicitly in

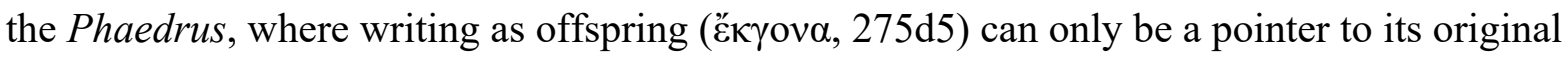
father ( $\tau$ oṽ $\pi \alpha \tau \rho o ́ \varsigma, 275 \mathrm{e} 4$ ) and remains dependent on him for explication and stability of meaning (Phdr. 275d4-e5); the argument has been illustrated with a story told by Socrates, in which letters are themselves the offspring of the god Theuth (274c5-275b2). ${ }^{34}$

In the Parmenides, the narrator repeats a story learned from Antiphon, the living repository of the conversation and Plato's step-brother (Prm. 126c6-8; see below), both the account of transmission and the role of Plato's brothers in facilitating it offer authentication. Providing family names and genealogies asserts a claim to historicity and realism for the central discussions contained within these dialogues (Halperin 1992).

${ }^{34}$ See Osborne 1999 for a discussion of the philosophical erotics of this dialogue. 
A standard way to explore the past in ancient thought was through the idea of generations and genealogies. ${ }^{35}$ Time becomes biological and reproductive, even though not all ancient lists that extend backwards into the past presuppose parental relationships as a means of that extension. King lists may not denote father-to-son biological inheritance, but do imply authorised succession and, often, processes of filiation. Queer theory provides a useful lens for exploring what is at stake in constructing alternative and non-familial genealogies. Queer accounts of genealogy note that many lives might not progress through the expected and normalised life stages presupposed by heteronormative social practices; such accounts can thus be used both to create hierarchies and to disrupt them, as David Halperin has shown in exploring the construction of the Symposium (Halperin 1986). The authority of genealogy is disrupted by queer challenges to filiation.

In several dialogues whose dramatic setting appears to be long before the crisis of the trial and execution, Socrates appears as a character intermediate in age to sets of fathers and sons. He is represented as a full adult, one too old to participate formally in pederastic relationships, but one who is eagerly consulted by boys who themselves are in the prime season for such relationships. The erotics of dialogues such as the Lysis and Charmides, with their gymnasium settings and exploration of pederastic relationships, play on this. Socrates' own children are absent from the dialogues, and not even brought out for effect at his trial (Apology 34c, 37cd). But Socrates' erotic filiations complicate his legacy in Athens; Charmides became one of the Ten who governed Piraeus under the Thirty tyrants (Xen. Hell. 2.4.19; see Nails 2002: 89-91). Alcibiades' fall from grace is hinted at in the Republic, while Athenian readers would have recognised Critias' role during the 404-3 BCE tyranny, as Aeschines points out (Against Timarchus 173).

${ }^{35}$ Bertelli 2001, Thomas 1989: 155-95. 
Eve Kosofsky Sedgwick presented her queer friendships as a disruption of a 'normal' progressions of generations, as her own and others' illnesses threaten the usual order:

A more recent contingency, in the brutal foreshortening of so many queer life spans, has deroutinized the temporality of so many of us. I'm thinking, as I say this, of three very queer friendships I have. One of my friends is sixty; the other two are both thirty, and I, at forty-five, am exactly in the middle... In a 'normal' generational narrative, our identifications with each other would be aligned with an expectation that in another fifteen years, I'd be situated comparably to where my sixty-year-old friend is, while my thirty-year-old friends would be situated comparably to where I am. But we are all aware that the grounds of such friendships today are likely to differ from that model. (Sedgwick 1997: 26-27)

Plato's use of pederasty to construct teacher-pupil relationships as a form of nonfamilial filiation itself has an anachronistic tone, emphasising the archaic valuation of the practice of pederasty whose continuation, outside nostalgic literary texts, is presented as problematic. ${ }^{36}$ Fourth-century literary sources beyond Plato often criticise aspects of the practice, through political attacks which present it in the degraded form of male prostitution, as in the notorious rivalry between Aeschines and Demosthenes seen in Against Timarchus. Pederastic imagery was out of fashion on Athenian painted pottery by the time Plato was writing, with most examples dating from the previous centuries (Osborne 2018). Just as Plato's evocation of Socrates looks back in time, his model of male-male relationships displays nostalgia for an imagined and idealised past form of a practice whose signification

${ }^{36}$ For Foucault, Athenian sources always problematised pederasty (Foucault 1985: 193-203), although at 191 he limits this to the fourth century; Andrew Lear points to a changing evaluation as education became professionalised in the late fifth century BCE (Lear 2004). 
had changed. ${ }^{37}$ In the mid-to-late fourth century, the character of the eromenos was under question and innocence and honour not assumed.

Other dialogues take this enquiry further. The Laches explores the topic of courage, within the context of education, and specifically the role of fathers in educating their sons and passing on their own skills to them. ${ }^{38}$ Of the main speakers in the dialogue, two, Lysimachus and Melesias, are fathers who have themselves failed to live up to the achievements of their own illustrious fathers Aristides and Thucydides, and seek to understand how their sons should be educated. They in turn discuss modes of education with two current Athenian generals, Laches and Nicias.

Socrates himself receives two introductions in the dialogue. The first is a conventional filiation, by patronymic and deme. ${ }^{39}$ When Socrates is first introduced to Lysimachus and

${ }^{37}$ Although, as a reviewer points out, other fourth-century authors also idealise such relationships. Aeschines presents both a nostalgic view (Against Timarchus 132-52), culminating in an examination of the relationship of Achilles and Patroclus, and a view which insists upon their contemporary reality in the lived experience of honourable men (Against Timarchus 155-7); but throughout this speech Aeschines offers an idealised and imaginary view of Athenian political and social customs. The Erotic Essay of pseudo-Demosthenes opens with the thought that being the object of erotic attention, especially in literary form,

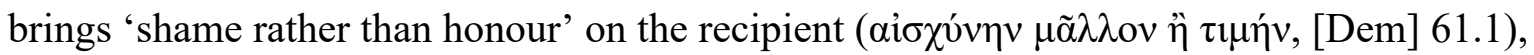
and continues rather defensively (see Foucault 1985: 204-6, Dover 2016: 42). Similar nostalgia might also be visible in the characterisation of pederasty given by the Right Argument of Aristophanes' Clouds (973-83).

${ }^{38}$ Emlyn-Jones 1999, Tessitore 1994.

${ }^{39}$ On Plato’s marked use of patronymics, see Burnyeat 2004. 
Melesias, Lysimachus remembers his friendship with Socrates' father, Sophroniscus, via their shared deme affiliation, although he has not previously connected Socrates with his father:

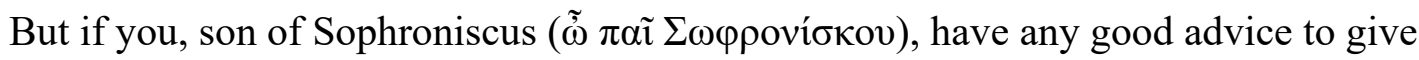
your fellow demesman, you ought to give it. And you have a duty to do so, because you are my friend through your father ( $\pi \alpha \tau \rho$ «ó $\varsigma)$. He and I were always comrades and

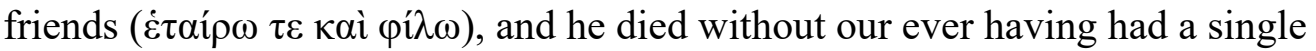
difference. (Laches 180d6-181a1)

The dual forms hetairo and philo suggest a close attachment, and Lysimachus asserts Socrates' paternal affiliation through addressing him as Sophroniscus' son. Later, Laches himself will provide a character reference for Socrates based upon his knowledge of his deeds, presumably a reference to Socrates' courageous behaviour in retreat at Athens' defeat at Delium in $424 \mathrm{BCE}$ :

I have no experience of the words of Socrates, but, I believe, I have had previous experience of his deeds, and there I found him worthy of fine words and all frankness. (Laches 188e5-189a1)

This second introduction poses a question. Is Laches' testimony based on knowledge of Socrates as an active citizen more telling than Lysimachus' assumption that he has inherited the virtues of his father, even though Lysimachus knows that he himself has failed to inherit his father's strengths?

In the Protagoras, on the other hand, we do not see fathers and sons together, but sons separated from their fathers, and thus, in Plato's partially metaphorical depiction of the social processes of pederasty, vulnerable to bad influences and to approaches from men who would go beyond the accepted limits of pederastic courtship. Callias has inherited his property from 
his father Hipponicus, and now hosts a crowd of visiting sophists. ${ }^{40}$ Socrates and Protagoras, along with the other sophists, are a dangerous presence to the young men eager for education. Hence, when the young Hippocrates seeks Socrates' advice independently of his father Apollodorus, Socrates voices concern:

But something you regard as more important than your body - your soul - something on which your entire wellbeing depends, depending on whether it ends up in a good or bad state - when it comes to that, you haven't consulted your father or your brother, or any of us who are your friends, about whether you should entrust your soul to this foreigner who has just arrived ... (Protagoras 313a6-b2)

Socrates emphasises this to Hippocrates in their initial conversation before they set out to Callias' house, where the sophists are staying. Here they find other young men eagerly listening to the visiting educators. The sons of Pericles follow Protagoras, and have a prime position in his retinue:

And when we got inside, we found Protagoras walking up and down in the procolonnade. And with him, walking up and down in formation, were on the one side Callias the son of Hipponicus, his half-brother Paralus the son of Pericles, and Charmides the son of Glaucon, and on the other side Pericles' other son Xanthippus, Philippides the son of Philomelus, and Antimoerus of Mende... (Protagoras 314e3315a4)

${ }^{40}$ This is one of the Platonic anachronisms identified by Athenaeus (Deipnosophists 5.218bc), who believes that Callias was not yet dead at the dialogue's presumed dramatic date of 434 BCE; see Zeller 1873: 84-85. 
Many of the others present at Callias' house are identified by their patronymics, emphasising the absence of their fathers. The incursion of sophistry into Athenian education has separated fathers and sons, and possibly disrupted the transmission of virtue from generation to generation. ${ }^{41}$ Protagoras even notes Pericles' failure, an ironic gloss by Plato on the biographical tradition, or perhaps its precursor:

Take Pericles, the father of these young men here - he gave them an admirable education in the things that can be got from teachers. But when it comes to his own wisdom, he neither educates them himself nor sends them to anyone else. Instead, they wander around on their own like sacred cattle, grazing on human goodness as and when they stumble on it left to themselves. (Prt. 319e3-320a3)

The sophists offer a connection to an alternative genealogy, one in which their skill and expertise link them back to poets in a lengthy succession, as Protagoras recounts. Within the context of Plato's dialogues, they displace the fathers' influence on their sons, just as Socrates was accused of doing. In drawing the youths into their circles, they generate their own genealogies, training followers who will succeed them.

Queer theorists have questioned the heteronormativity of genealogical models and the assumption of familial succession. Creating new families outside or beyond the framework of the genetic family is a queer theory project undertaken by, for example, Judith Butler, in her reshaping of the Oedipus myth centred on Antigone, marking the refusal of futurity. ${ }^{42}$ Lee Edelman's objections to 'reproductive futurity' have different resonances in a world where

${ }^{41}$ Plato follows Aristophanes in this thought.

${ }^{42}$ Butler 2000, Halberstam 2011: 72-73. Another related view, proposed by Donna Haraway, is that the critical conditions of the present epoch necessitate the remaking of kinship (Haraway 2016: 102-3). 
equal marriage and reproductive technologies have enabled a wider range of families to become established and to rear their own children. ${ }^{43}$ Maggie Nelson's The Argonauts traces its writer's experience of living in a relationship in which normative gender identities are in flux; she describes her own longing for a successful conception as generating ambivalence towards the queer rejection of reproductive futurism, drawing a difference between the individual child and the symbolic 'Child' identified by Edelman (Nelson 2015: 75-76).

Although Plato reconstructs intergenerational connections, he does not reject the view of a developmental path through life. Plato simply has Socrates replace the father figure in a young man's genealogy, in order to ensure the proper development of sons; and the sons themselves are envisaged as engaged in reproducing ideas as their offspring. Like the standard model of education and progression through ranks of citizenship seen in the ageclass system, he outlines a desirable path of personal growth that takes a firmly linear and teleological form as suitable students rise through the ranks towards the possibility of an encounter with the Form of the Good. Although the goal of the path is different, and the mode of education different, the linear progress required is the same. Plato's programme perhaps offers a queered alternative to the path anticipated by biological genealogy and reproductive futurism.

The Symposium is set in a household where the kurios male lives at least part of his life in a non-sanctioned same-sex relationship that falls outside the recognised and normative age limits for pederasty. ${ }^{44}$ It also marks a stage in the development of Alcibiades, whom we see in several dialogues; the sub-genre of erotic dialogue, often featuring Socrates and

${ }^{43}$ Edelman 2004, Muñoz 2009, Marriott 2011.

${ }^{44}$ Gilhuly 2009; Halperin 1990, cf. the depiction of Agathon in Aristophanes' Thesmophoriazusae. 
Alcibiades, was used by Plato as by other Socratics. ${ }^{45}$ In the Protagoras, as we saw, the dialogue's temporality is initially framed around the physical maturation of Alcibiades. ${ }^{46}$ His moment of blossoming at the transition to adulthood offers a kairos, an opportunity to intervene. In the Symposium, that intervention is problematized and evidently on the path to failure. In the Republic, unnamed youths who have fallen from the path of philosophy appear to share some of Alcibiades' traits, and the dangers of such characters are explored (6.490d493a).

Choosing the non-philosophical life is an alternative recognised in Plato's framework. The Parmenides recounts a version of the conversation told by Antiphon, the half-brother of Adeimantus and Glaucon, Plato's brothers. Antiphon has given up philosophy for the more usual pursuits of a gentleman-farmer. He is extremely reluctant to retell the conversation of Socrates with Parmenides and Zeno, even though he rehearsed it meticulously when he was younger. But now he has followed his family's practices rather than those of Socrates:

For when he was a lad he studied these arguments extensively, but now (ṽv $\gamma \varepsilon)$ just like his grandfather and namesake ( time on horsey matters. (Prm. 126c6-8)

The choice of the philosophical life is not an irretrievable one; filiation to the Socratic genealogy is a reversible choice. While Socrates uses Diotima to sketch out one possible route to knowledge, Antiphon in his return to both his familial environment, and even the reproductive work of horse-breeding, represents the rejection of philosophy and the queered filiation Plato presents it as requiring. Although the narrator, he remains outside the

\footnotetext{
${ }^{45}$ Cf. Wohl 1999.

${ }^{46}$ A setting replicated in the disputed Alcibiades I (103ab).
} 
philosophical discussion in a dialogue that Jill Gordon has described as 'highly erotically charged' (Gordon 2012: 86).

\section{Conclusion}

Plato's writing has been a major influence on the development of queer theory, informing the scholarship of Foucault, Halperin and others. However, there has been little explicit use of queer theory in return as a framework within which to read Platonic dialogue, despite the centrality of Plato and key episodes such as the Symposium's Aristophanic myth to queer theory and culture more broadly. Models of queer time provide a key to understanding Plato's anachronisms, while the queer theory problematisation of familial relationships and their role in analogies of filiation and genealogy provide a perspective on Plato's account of familial relations and their disruption by Socrates' teaching.

The sense of crisis and loss that permeates Plato's accounts of Socrates and his other characters makes the crisis literature of both ends of the twentieth century an analogy that provides additional context for Plato's writing. Although Graves, Sedgwick, and Nelson write about different moments of political and personal crisis, their work connects to Plato through the lived disruption of temporality. Above all, queer theories of affective time provide an explanation for the multiple temporalities and repeated emphasis on filiation of Plato's Socratic dialogues, illuminating a new way to read and receive these foundational texts. 


\section{Acknowledgements}

This paper has developed from the one I presented at the Anachronism and Antiquity conference; I am grateful to fellow participants and the audience for some acute questions, and to John Marincola and his colleagues at Florida State University for their hospitality. My colleagues on the Anachronism and Antiquity project provided further commentary as the paper developed and this journal issue took shape. I'm particularly grateful to Ika Willis and Sara Monoson for discussing their work with me, and to Mathura Umachandran and the anonymous reviewer for CRJ for their insightful comments and suggestions.

\section{References}

J. Annas, 'Plato's Republic and Feminism', Philosophy 51 (1976), pp. 307-21.

S. M. Barber and D. L. Clark, 'Queer Moments: the performative temporalities of Eve Sedgwick', in S. M. Barber and D. L. Clark (eds.), Regarding Sedgwick: Essays on Queer Culture and Critical Theory (New York: Routledge, 2002), pp. 1-53.

L. Bertelli, 'Hecataeus: from genealogy to historiography', in N. Luraghi (ed.), The Historian's Craft in the Age of Herodotus (Oxford: Oxford University Press, 2001), pp. 67-94.

G. Betegh, The Derveni Papyrus: Cosmology, Theology and Interpretation (Cambridge: Cambridge University Press, 2004).

R. Blondell and K. Ormand (eds.), Ancient Sex: New Essays (Columbus: The Ohio State University Press, 2015).

F. Brearton, 'A War of Friendship: Robert Graves and Siegfried Sassoon', in T. Kendall (ed.), The Oxford Handbook of British and Irish War Poetry (Oxford: Oxford University Press, 2009), pp. 208-26.

S. Broadie, Nature and Divinity in Plato's Timaeus (Cambridge: Cambridge University Press, 2012).

M. F. Burnyeat, 'First words: a valedictory lecture', Proceedings of the Cambridge Philological Society 43 (1998), pp. 1-20.

_ ' 'Fathers and Sons in Plato's Republic and Philebus', Classical Quarterly 54, no. 1 (2004), pp. 80-87.

M. F. Burnyeat and M. Frede, The Pseudo-Platonic Seventh Letter (Oxford: Oxford University Press, 2015).

J. Butler, Antigone's Claim: kinship between life and death (New York: Columbia University Press, 2000). 
T. Dean, 'Bareback Time', in E. L. McCallum and M. Tuhkanen (eds.), Queer Times, Queer Becomings (Albany: SUNY Press, 2011), pp. 75-99.

J. Derrida, Dissemination, tr. B. Johnson (London: Athlone Press, 1981).

- The Post Card: from Socrates to Freud and Beyond, tr. A. Bass (Chicago: University of Chicago Press, 1987).

C. Dinshaw, 'Temporalities', in P. Strohm (ed.), Middle English (Oxford: Oxford University Press, 2007), pp. 107-23.

- How Soon Is Now?: Medieval Texts, Amateur Readers, and the Queerness of Time (Durham: Duke University Press, 2012).

K. J. Dover, Greek Homosexuality, ed. S. Halliwell, M. Masterson, and J. Robson, (New edn.; London: Bloomsbury, 2016 [1978]).

N. H. Drake. 1970. 'World War I in the Life and Poetry of Robert Graves', MA dissertation, University of North Texas.

F. M. Dunn, 'Protagoras and the Parts of Time', Hermes 129, no. 4 (2001), pp. 547-50.

_ , Present Shock in Late Fifth-century Greece (Ann Arbor: University of Michigan Press, 2007).

L. Edelman, No Future: queer theory and the death drive (Durham: Duke University Press, 2004).

C. Emlyn-Jones, 'Dramatic Structure and Cultural Context in Plato's Laches', Classical Quarterly 49, no. 1 (1999), pp. 123-38.

M. Foucault, Archaeology of Knowledge, tr. A. M. S. Smith (New York: Harper \& Row, 1976).

—, 'Nietzsche, Genealogy, History', in D. F. Bouchard (ed.), Language, Countermemory, Practice: selected essays and interviews (Ithaca: Cornell University Press, 1977), pp. 139-64.

- The History of Sexuality: the Will to Knowledge (Vol. 1), tr. R. Hurley (London: Penguin, 1978).

- The History of Sexuality: The Use of Pleasure (Vol. 2), tr. R. Hurley (London: Penguin Books, 1985).

M. Frede, 'Being and Becoming in Plato', in J. Annas and R. H. Grimm (eds.), Oxford Studies in Ancient Philosophy, Supplementary Volume (1988), pp. 37-52.

E. Freeman, 'Introduction', GLQ: A Journal of Lesbian and Gay Studies 13, no. 2-3 (2007), pp. $159-76$.

_ Time Binds: queer temporalities, queer histories (Durham: Duke University Press, 2010).

J. Gallop, 'Sedgwick's twisted temporalities', in E. L. McCallum and M. Tuhkanen (eds.), Queer Times, Queer Becomings (Albany: SUNY Press, 2011), pp. 68-74.

K. Gilhuly, The Feminine Matrix of Sex and Gender in Classical Athens (Cambridge: Cambridge University Press, 2009).

C. Gill, 'The Genre of the Atlantis Story', Classical Philology 72, no. 4 (1977), pp. 287-304. 
J. Gordon, Plato's Erotic World: from cosmic origins to human death (Cambridge:

Cambridge University Press, 2012).

J. Graham, 'Plato's Anachronisms', in N. Sekunda (ed.), Corolla Cosmo Rodewald (Gdańsk: Foundation for the Development of Gdańsk University, 2007), pp. 67-74.

R. Graves, Over the Brazier (London: The Poetry Bookshop, 1916). , Goodbye to All That (London: Penguin, 1960 [1929]).

E. Greenwood, 'Futures Real and Unreal in Greek Historiography', in A. Lianeri (ed.), Knowing Future Time in and through Greek Historiography (Berlin: De Gruyter, 2016), pp. 55-76.

J. Halberstam, In a Queer Time and Place: Transgender Bodies, Subcultural Lives (New York: New York University Press, 2005).

, The Queer Art of Failure, (Durham: Duke University Press, 2011).

D. M. Halperin, 'Plato and Erotic Reciprocity', Classical Antiquity 5, no. 1 (1986), pp. 60-80. , One Hundred Years of Homosexuality: and other essays on Greek love (London: Routledge, 1990). , 'Plato and the Erotics of Narrativity', in J. C. Klagge and N. Smith, D. (eds.), Methods of Interpreting Plato and his Dialogues (Oxford: Clarendon Press, 1992), pp. 93-129.

D. J. Haraway, Staying with the Trouble: making kin in the Chthulucene (Durham: Duke University Press, 2016).

L. Irigaray, Speculum of the Other Woman, tr. G. C. Gill (Ithaca: Cornell University Press, 1985).

A. Jagose, Queer Theory: an introduction (New York: New York University Press, 1996).

A. Lear. 2004. 'Noble Eros: The idealization of pederasty from the Greek Dark Ages to the Athens of Socrates', Ph.D dissertation, University of California, Los Angeles.

A. Lianeri, 'The Futures of Greek Historiography', in A. Lianeri (ed.), The Futures of Greek Historiography (Berlin: De Gruyter, 2016), pp. 1-54.

N. Loraux, The Children of Athena: Athenian Ideas About Citizenship and the Division Between the Sexes, tr. C. Levine (Princeton: Princeton University Press, 1993).

D. Marriott, 'No second chances', in E. L. McCallum and M. Tuhkanen (eds.), Queer Times, Queer Becomings (Albany: SUNY Press, 2011), pp. 101-20.

M. H. Miller, Plato's Parmenides: the Conversion of the Soul (Princeton: Princeton University Press, 1986).

S. S. Monoson, 'Socrates in Combat: Trauma and Resilience in Plato's Political Theory', in P. Meineck and D. Konstan (eds.), Combat Trauma and the Ancient Greeks (New York: Palgrave Macmillan, 2014), pp. 131-62.

J. E. Muñoz, Cruising Utopia: the then and there of queer futurity (New York: New York University Press, 2009).

D. Nails, The People of Plato: a prosopography of Plato and other Socratics (Indianapolis: Hackett, 2002).

M. Nelson, The Argonauts, (Minneapolis: Graywolf, 2015). 
C. Osborne, "No" Means "Yes": the Seduction of the Word in Plato's Phaedrus', Boston Area Colloquium in Ancient Philosophy 15, no. 1 (1999), pp. 263-81.

R. Osborne, 'Imaginary Intercourse: an Illustrated History of Greek Pederasty', in P. Christesen, D. S. Allen and P. Millett (eds.), How To Do Things With History (Oxford: Oxford University Press, 2018), pp. 313-38.

S. Rangos, 'Plato on the Nature of the Sudden Moment, and the Asymmetry of the Second Part of the Parmenides', Dialogue 53, no. 3 (2014), pp. 538-74.

V. Rohy, Anachronism and its Others: sexuality, race, temporality (Albany: SUNY Press, 2009).

, 'Busy Dying', in B. Davies and J. Funke (eds.), Sex, Gender and Time in Fiction and Culture (Basingstoke: Palgrave Macmillan, 2011), pp. 205-19.

- Lost Causes: narrative, etiology, and queer theory (New York: Oxford University Press, 2015).

M. Schofield, 'Plato and Practical Politics', in C. J. Rowe and M. Schofield (eds.), The Cambridge History of Greek and Roman Political Thought (Cambridge: Cambridge University Press, 2000), pp. 293-302.

D. Scott, Plato's Meno (Cambridge: Cambridge University Press, 2006).

E. K. Sedgwick, Epistemology of the Closet (Berkeley: University of California Press, 1990). , Tendencies (London: Routledge, 1994).

, 'Paranoid Reading and Reparative Reading; or, You're So Paranoid, You Probably Think This Introduction Is about You', in E. K. Sedgwick (ed.), Novel Gazing: queer readings in fiction (Durham: Duke University Press, 1997), pp. 1-37.

B.S. Strauss, Fathers and Sons in Athens: ideology and society in the era of the Peloponnesian War (London: Routledge, 1993).

L. Strauss, 'Persecution and the Art of Writing', Social Research 8, no. 1 (1941), pp. 488504.

A. Tessitore, 'Courage and Comedy in Plato's Laches', Journal of Politics 56, no. 1 (1994), pp. 115-33.

R. Thomas, Oral Tradition and Written Record in Classical Athens (Cambridge: Cambridge University Press, 1989).

V. Traub, 'The New Unhistoricism in Queer Studies', Publications of the Modern Language Association of America 128, no. 1 (2013), pp. 21-39.

W. B. Turner, A Genealogy of Queer Theory (Philadelphia: Temple University Press, 2000).

G. Vlastos, Socrates, Ironist And Moral Philosopher (Ithaca: Cornell University Press, 1991).

I. Willis, 'Eros in the Age of Technical Reproductibility: Socrates, Plato, and the Erotics of Filiation', in M. Leonard (ed.), Derrida and Antiquity (Oxford: Oxford University Press, 2010), pp. 343-69.

S. Winnubst, 'Temporality in Queer Theory and Continental Philosophy', Philosophy Compass 5, no. 2 (2010), pp. 136-46.

V. Wohl, 'Plato avant la lettre', Ramus 27, no. 1 (1998), pp. 60-93. , 'The Eros of Alcibiades', Classical Antiquity 18, no. 2 (1999), pp. 349-85. 
- Love Among the Ruins: the Erotics of Democracy in Classical Athens (Princeton: Princeton University Press, 2002).

E. Zeller, 'Über die Anachronismen in den platonischen Gesprächen', Abhandlungen der Königlichen Akademie der Wissenschaften zu Berlin (1873), pp. 79-99. 